\title{
HUBUNGAN PENGETAHUAN DENGAN SIKAP SUAMI TERHADAP METODE KONTRASEPSI VASEKTOMI DI BANJAR PENESTANAN KELOD KABUPATEN GIANYAR
}

\author{
Kadek Widiantari ${ }^{1,2}$, Ni Wayan Ari Suantari ${ }^{1,2}$ \\ ${ }^{1}$ Prodi DIII Kebidanan, ${ }^{2}$ Politeknik Kesehatan Kartini Bali \\ Korespodensi penulis: diantari808@gmail.com
}

\begin{abstract}
Abstrak
Latar belakang dan tujuan: Laju pertumbuhan penduduk merupakan salah satu permasalahan yang dialami oleh negara berkembang termasuk Indonesia. Upaya pemerintah untuk menekan laju pertumbuhan salah satunya dengan mengadakan program Keluarga Berencana (KB), khususnya dengan meningkatkan peran serta suami dalam menggunakan metode kontrasepsi vasektomi. Penelitian ini bertujuan untuk mengetahui hubungan pengetahuan dengan sikap suami terhadap metode kontrasepsi vasektomi.

Metode: Desain penelitian ini merupakan jenis penelitian analitik korelasi dengan pendekatan cross-cectional. Populasi dalam penelitian ini adalah semua pria Pasangan Usia Subur di banjar penestanan kelod, desa sayan, kecamatan ubud yang berjumlah 256 pasangan. Pemilihan subyek menggunakan teknik purposive sampling dengan jumlah sampel sebanyak 65 orang. Instrumen yang digunakan dalam pengumpulan data yaitu kuesioner. Analisis data yang digunakan adalah analisa univariate, Bivariate dengan menggunakan uji statistik Pearson Chi-square.

Hasil: Penelitian menunjukkan bahwa sebagian besar responden yaitu sebanyak 37 responden $(56,9 \%)$ memiliki pengetahuan yang kurang, dan hampir seluruhnya yaitu 53 responden ( $81,5 \%)$ memiliki sikap negatif terhadap metode kontrasepsi vasektomi. Hasil analisis bivariat menunjukkan terdapat hubungan antara pengetahuan dengan sikap suami terhadap metode kontrasepsi vasektomi $(p<0,005)$

Simpulan: Ada hubungan yang signifikan antara pengetahuan dengan sikap suami terhadap Metode kontrasepsi vasektomi.
\end{abstract}

Kata kunci: Pengetahuan, Sikap, Suami, Vasektomi

\section{Pendahuluan}

Indonesia merupakan negara dengan penduduk terbanyak keempat di dunia dan masih memiliki banyak masalah kependudukan yang belum bisa teratasi hingga saat ini, salah satunya yaitu laju pertumbuhan penduduk. Laju pertumbuhan penduduk di Indonesia mengalami peningkatan cukup pesat dari tahun ke tahun. Pada tahun 1990 berjumlah 179.378.946 jiwa yang kemudian meningkat pada tahun 2010 menjadi 237.641.324 jiwa. Selama kurun waktu 20 tahun terjadi lonjakan sebesar 197,4 juta jiwa (BKKBN, 2016)
Upaya yang dilakukan pemerintah dalam mengatasi masalah peningkatan jumlah penduduk yaitu dengan mencanangkan program Keluarga Berencana (KB) Nasional. Program KB tidak hanya ditujukan untuk penurunan angka kelahiran, namun dikaitkan pula dengan tujuan untuk pemenuhan hakhak reproduksi, promosi, pencegahan dan penanganan masalah-masalah kesehatan reproduksi seksual, kesehatan dan kesejahteraan ibu, bayi dan anak (BKKBN, 2010).

Hasil Survei Demografi dan Kesehatan Indonesia (SDKI) tahun 2012 menunjukkan 
bahwa pemakaian kontrasepsi pria hanya 2 persen dari total pemakaian kontrasepsi (kondom 1,8\% dan vasektomi 0,2\%). Data tersebut mempertegas bahwa keikutsertaan pria dalam mengikuti program KB masih sangat rendah terutama dalam penggunaan metode vasektomi. Vasektomi adalah suatu metode kontrasepsi operatif minor pada pria yang sangat aman, sederhana dan efektif serta memakan waktu operasi yang singkat dan tidak memerlukan anestesi umum (Handayani, 2010). Kurangnya pengetahuan suami tentang alat kontrasepsi pria dan terbatasnya variasi kontrasepsi menjadi salah satu penyebab rendahnya KB pria di Indonesia (BKKBN, 2015).

Gianyar merupakan salah satu kabupaten di Bali dengan jumlah pasangan usia subur sebanyak 81.534 orang dengan pencapaian KB pria terendah yaitu sebanyak 360 orang $(36,07 \%)$. Pasangan usia subur di Kabupaten Gianyar paling banyak menggunakan IUD yaitu $49,1 \%$ dan paling sedikit menggunakan metode vasektomi sebanyak 2,3\% (BKKBN Kab.Gianyar, 2016).Berdasarkan studi pendahuluan yang dilakukan peneliti dengan 10 suami Pasangan Usia Subur di Banjar Penestanan Kelod Desa Sayan Kecamatan Ubud, ditemukan $70 \%$ suami belum paham mengenai metode vasektomi dan 30\% dari suami pasangan usia subur telah mengetahui informasi mengenai metode vasektomi dan dari 10 orang yang diwawancarai belum ada yang menggunakan metode kontrasepsi vasektomi.

\section{Metode Penelitian}

Penelitian ini termasuk dalam penelitian analitik korelasional yang dilakukan untuk mengetahui hubungan antara dua variabel mengenai ada tidaknya hubungan pengetahuan dan sikap suami usia subur terhadap metode kontrasepsi vasektomi. Peneliti menggunakan pendekatan cross sectional dimana data variabel independen (pengetahuan suami tentang metode kontrasepsi vasektomi) dan variabel dependent (sikap suami terhadap metode kontrasepsi vasektomi) pada responden penelitian diambil dan dikorelasikan dalam kurun waktu yang bersamaan.

Sampel dalam penelitian ini adalah suami Pasangan Usia Subur yang memiliki anak lebih dari dua orang berjumlah 65 responden. Teknik sampling yang digunakan adalah purposive sampling. Data dianalisis dengan menggunakan uji statistik Pearson Chisquare.

\section{Hasil dan Pembahasan}

Tabel 1 menunjukkan umur responden, sebagian besar yaitu 41 responden $(63,1 \%)$ berumur lebih dari 35 tahun.sedangkan pada tabel 2 menunjukkan sebagian besar yaitu 41 responden $\quad(63,1 \%) \quad$ berpendidikan SMA/SMK dan pada tabel 3 menunjukkan jumlah anak, dimana hampir seluruhnya yaitu 49 responden (75,4\%) memiliki anak sebanyak 3 orang. Tabel 4 menunjukkan sebagian besar yaitu sebanyak 37 responden $(56,9 \%)$ memiliki pengetahuan yang kurang dan Tabel 5 menunjukkan hampir seluruhnya yaitu 53 responden $(81,5 \%)$ memiliki sikap yang negatif.

Tabel 1. Karakteristik Responden Berdasarkan Umur

\begin{tabular}{llcc}
\hline No & Kelompok Umur & Frekuensi (f) & Persentase (\%) \\
\hline 1 & $<35$ tahun & 24 & 36,9 \\
\hline 2 & $>35$ tahun & 41 & 63,1 \\
\hline & Jumlah & 65 & 100 \\
\hline
\end{tabular}

Sumber : Data Primer Penelitian, 2018 
e-ISSN : 2614-5685

p-ISSN : 2614-5421

Tabel 2. Karakteristik Responden Berdasarkan Pendidikan Terakhir

\begin{tabular}{llcc}
\hline No & Pendidikan Terakhir & Frekuensi (f) & Persentase (\%) \\
\hline 1 & SD & 4 & 6,2 \\
\hline 2 & SMP & 15 & 23,1 \\
\hline 3 & SMA/SMK & 41 & 63,1 \\
\hline 4 & Perguruan Tinggi (PT) & 5 & 7,7 \\
\hline & Jumlah & 65 & 100
\end{tabular}

Sumber : Data Primer Penelitian, 2018

Tabel 3. Karakteristik Responden Berdasarkan Jumlah Anak

\begin{tabular}{llcc}
\hline No & Jumlah Anak & Frekuensi (f) & Persentase (\%) \\
\hline 1 & 3 Orang & 49 & 75,4 \\
\hline 2 & $>3$ Orang & 16 & 24,6 \\
\hline & Jumlah & 65 & 100 \\
\hline
\end{tabular}

Sumber : Data Primer Penelitian, 2018

Tabel 4. Distribusi Frekuensi Pengetahuan Suami Tentang Metode Kontrasepsi Vasektomi

\begin{tabular}{llcc}
\hline No & Pengetahuan & Frekuensi (f) & Presentase (\%) \\
\hline 1 & Baik & 10 & 15,4 \\
\hline 2 & Cukup & 18 & 27,7 \\
\hline 3 & Kurang & 37 & 56,9 \\
\hline & Jumlah & 65 & 100 \\
\hline
\end{tabular}

Sumber : Data Primer Penelitian, 2018

Tabel 5. Distribusi Frekuensi Sikap Suami Terhadap Metode Kontrasepsi Vasektomi

\begin{tabular}{llcc}
\hline No & Sikap & Frekuensi (f) & Presentase (\%) \\
\hline 1 & Positif & 12 & 18,5 \\
\hline 2 & Negatif & 53 & 81,5 \\
\hline & Jumlah & 65 & 100 \\
\hline
\end{tabular}

Sumber : Data Primer Penelitian, 2018

Tabel 6. Hubungan Pengetahuan dengan Sikap Suami Terhadap Metode Kontrasepsi Vasektomi

\begin{tabular}{|c|c|c|c|c|c|c|c|}
\hline \multirow{3}{*}{ No } & \multirow{3}{*}{ Pengetahuan } & \multicolumn{4}{|c|}{ Sikap } & \multirow{2}{*}{\multicolumn{2}{|c|}{ Total }} \\
\hline & & \multicolumn{2}{|c|}{ Positif } & \multicolumn{2}{|c|}{ Negatif } & & \\
\hline & & $\mathbf{F}$ & $\%$ & $\mathbf{F}$ & $\%$ & f & $\%$ \\
\hline 1 & Baik & 7 & 70,0 & 3 & 30,0 & 10 & 100,0 \\
\hline 2 & Cukup & 4 & 22,2 & 14 & 77,8 & 18 & 100,0 \\
\hline 3 & Kurang & 1 & 2,7 & 36 & 97,3 & 37 & 100 \\
\hline
\end{tabular}

Tabel 6 menunjukkan bahwa, dari 65 responden, sebagian besar memiliki pengetahuan kurang yaitu sebanyak 37 responden. Dari 37 responden yang memiliki pengetahuan kurang, hampir seluruhnya yaitu 36 responden memiliki sikap negatif terhadap metode konstrasepsi vasektomi. Hal ini menunjukkan bahwa suami yang memiliki pengetahuan kurang cenderung menunjukkan sikap yang negatif.

Hasil ini sejalan dengan penelitian yang dilakukan oleh Nurrita tahun 2012 tentang Hubungan Pengetahuan dan Sikap Suami Terhadap Kontrasepsi Vasektomi di
Kecamatan Rancaekek menunjukkan hampir setengahnya responden memiliki pengetahuan yang kurang terhadap kontrasepsi vasektomi dan hampir seluruhnya responden memiliki sikap negatif terhadap kontrasepsi vasektomi. Menurut Sari, R \&, Nurfitriani (2016) Sikap dan pengetahuan saling berkaitan dalam membentuk perilaku seseorang. Pengetahuan yang baik diharapkan membuat seseorang agar menyaring informasi dengan baik agar memiliki sikap dan perilaku yang baik. Namun, terkadang masih ditemukan pengetahuan yang baik tidak selalu diikuti 
dengan sikap yang baik, begitu juga sebaliknya.

Pernyataan tersebut ditegaskan kembali dari hasil uji chi square yang menunjukkan bahwa terdapat hubungan signifikan antara pengetahuan dengan sikap suami terhadap metode kontrasepsi vasektomi di Banjar Penestanan Kelod, Desa Sayan, Kecamatan Ubud, Kabupaten Gianyar yang dapat dilihat dari nilai signifikasinya adalah 0,000 . Jadi nilai signifikasi hitung $(\mathrm{p}=0,000)$ lebih kecil dari nilai signifikasi tabel $(p=<0,05)$. Hasil ini sesuai dengan teori dari (Sasmita, A, 2015) yang menyatakan bahwa pengetahuan atau kognitif merupakan domain yang sangat penting untuk terbentuknya tindakan seseorang (ovent behavior). Suami yang memiliki pengetahuan kurang cenderung menunjukkan sikap negatif yaitu menolak untuk melakukan vasektomi karena ketidaktahuan mereka akan manfaat dan keamanannya bagi pasangan suami istri.

\section{Simpulan}

Terdapat hubungan yang nyata dan signifikan antara pengetahuan dengan sikap suami terhadap metode konstrasepsi vasektomi di Banjar Penestanan Kelod, Kabupaten Gianyar.

\section{Referensi}

BKKBN. 2010. Hari Kontrasepsi Dunia, Dunia diingatkan Pentingnya Keluarga Berencana dan Kesehatan Reproduksi. Jakarta : Jurnal Keluarga Informasi Kependudukan dan KB, Edisi September 2010.

BKKBN. 2016. Kebijakan Program Kependudukan, Keluarga Berencana, dan Pembangunan Keluarga dalam Mendukung Keluarga Sehat. Jakarta: PT. Bina Pustaka.

Handayani, S. 2010. Buku Ajar Pelayanan Keluarga Berencana. Yogyakarta: Pustaka Rihama

Nurrita, M. 2012. Pengetahuan Dan Sikap Suami Terhadap Kontrasepsi Mantap Vasektomi Di Kecamatan
Rancaekek. Students e-Journal, 1(1), 29.

Sari, R., \& Nurfitriani, N. 2018. Gambaran Pengetahuan Dan Sikap Pria Produktif Terhadap Metode Kontrasepsi Vasektomi dii Wilayah Kerja Puskesmas Rawasari. Jurnal Akademika Baiturrahim Jambi, 5(1), 14-18

Sasmita, A. 2015. Hubungan Antara Pengetahuan Dengan Pemilihan Kontrasepsi Pria (Vasektomi) Di Uptd Puskesmas Kampung Bali Kecamatan Pontianak Kota Tahun 2015. Jurnal ProNers, 3(1).

SDKI. 2012. Data Survei Demografi dan Kesehatan Indonesia. Jakarta 